\title{
PENGARUH MEDIA ARANG KAYU JATI PADA PROSES PACK CARBURIZING TERHADAP KOMPOSISI KIMIA DAN KEKERASAN BAJA KARBON RENDAH
}

\author{
Shultoni Mahardika ${ }^{1}$, Mohammad Thoriqul Hidayat ${ }^{2}$, \\ ${ }^{1,2}$ Prodi Teknik Mesin, Fakultas Teknik, Universitas Qomaruddin \\ 1mahardika89@uqgresik.ac.id \\ 2mohthoriqulhidayat@gmail.com
}

\begin{abstract}
Abstrak - Baja karbon rendah adalah baja dengan kandungan unsur karbon kurang dari $0,25 \%$. Baja jenis ini banyak dipakai pada spare part motor produk after market. Produk jenis ini memiliki tingkat kekerasan yang lebih rendah jika dibandingkan dengan produk Genuine Parts. Disebabkan rendahnya nilai kekerasan bahan bajanya jika dibandingkan produk Genuine Parts maka produk ini lebih cepat aus. Dikarenakan hal tersebut maka dilakukan rekayasa untuk peningkatan kekerasan baja. Salah satu caranya yakni dengan metode pack carburizing. Proses pack carburizing pada penelitian ini menggunakan media arang kayu jati sebagai carburizer. Proses ini dilakukan dengan melakukan pre-heating pada material yang berada di dalam kotak pack carburizing dengan suhu $650^{\circ} \mathrm{C}$. Setelah pre-heating kemudian suhu dinaikkan menjadi $900^{\circ} \mathrm{C}$ dan dilakukan waktu penahanan berbeda yakni 5,6 , dan 7 jam. Setelah itu dilakukan proses pendinginan dengan air. Hasil yang didapatkan material yang mengalami pack carburizing memiliki nilai karbon yang lebih tinggi seiring dengan bertambahnya waktu penahanan yang diberikan. Nilai karbon sebelum perlakuan yakni $0,12 \%$, kemudian terjadi peningkatan menjadi $1,03 \%$ pada waktu penahanan 5 jam, $1,18 \%$ pada waktu penahanan 6 jam dan $1,37 \%$ pada waktu penahanan 7 jam. Hasil pengujian kekerasan sebelum perlakuan yakni 46,4 HRA rata-rata meningkat menjadi 83,66 HRA, 84,69 HRA dan 84, 82 HRA pada penahanan 5 jam, 6 jam dan 7 jam. Namun saat dilakukan uji statistik, tidak disarankan untuk dilakukan penahanan waktu pemanasan hingga 7 jam jika menggunakan media ini. Hal ini disebabkan hasil perbandingan perubahan kekerasan antara waktu penahanan 6 jam dengan 7 jam tidak terdapat kenaikan kekerasan yang cukup signifikan..
\end{abstract}

Kata Kunci-Pack Carburizing;Uji Kekerasan; Arang Kayu Jati.

\begin{abstract}
Low carbon steel is steel with a carbon element content of less than $0.25 \%$. This type of steel is widely used in spare parts motorbikeproducts after market. This type of product has a lower hardness level when compared toproducts Genuine Parts. Due to the low hardness value of the steel material when compared to Genuine Parts products, this product wears out faster. Due to this, engineering was carried out to increase the hardness of steel. One way is by using themethod pack carburizing. Theprocess pack carburizing in this study uses teak wood charcoal as a carburizer. This process is done by pre-heating the material in thebox carburizing pack at a temperature of $650 \mathrm{C}$. After pre-heating, the temperature was increased to $900^{\circ} \mathrm{C}$ and different holding times were carried out, namely 5.6 and 7 hours. After that, the cooling process is carried out with water. The results obtained were that thematerial pack carburized had a higher carbon value as the holding time increased. The carbon value before treatment was $0.12 \%$, then there was an increase to $1.03 \%$ at the holding time of 5 hours, $1.18 \%$ at the holding time of 6 hours and $1.37 \%$ at the holding time of 7 hours. The results of the hardness testing before treatment were 46.4 HRA on average increased to 83.66 HRA, 84.69 HRA and 84, 82 HRA at 5 hours, 6 hours and 7 hours detention. However, when doing statistical tests, it is not recommended to hold the heating time up to 7 hours when using this medium. This is because the comparison of changes in violence between 6 hours and 7 hours of detention did not show a significant increase in violence.
\end{abstract}

Keywords-Carburizing Pack; Hardness Test; Teak Wood Charcoal.

\section{PENDAHULUAN}

Baja karbon rendah adalah sebuah baja dengan kandungan karbon pada komposisi kimianya kurang dari $0,25 \%$ dari keseluruhan berat baja. Baja jenis ini mempunyai keunggulan mudah dibentuk, sehingga banyak digunakan untuk membuat plat lembaran, batangan, baja struktur, baja profil dan lain sebagainya[1][2].

Aplikasi baja karbon rendah digunakan pula untuk membuat komponen spare part motor produk after market. Spare parts motor produk after market yakni sebuah Spare parts pilihan yang dapat dibeli di luar produk yang direkomendasikan dealer motor. Produk yang direkomendasikan dealer motor yang disebut produk Genuine Parts. Produk after market diminati karena harganya yang lebih murah, namun secara kualitas masih dibawah produk Genuine Parts[3].

Kebanyakan produk Spare parts after market motor memiliki kekurangan yakni umur pakainya yang lebih rendah. Masalah ini disebabkan karena produk jenis ini lebih cepat aus. Keausan tersebut disebabkan produk ini memiliki nilai 
kekerasan yang lebih rendah, jika dibandingkan dengan produk Genuine Parts. Untuk mengatasi problem tersebut diperlukan sebuah rekayasa untuk meningkatkan ketahanan aus produk. Cara peningkatan ketahanan aus produk tersebut adalah dengan meningkatkan kekerasan bajanya. Salah satu bentuk peningkatan kekerasan baja karbon rendah yang dapat digunakan yakni Pack Carburizing[4].

Pack Carburizing adalah proses menambahkan unsur karbon ke permukaan material, sehingga mengakibatkan kekerasan permukaan material bertambah [5]. Terdapat beberapa faktor yang mempengaruhi hasil akhir dari proses pack carburizing yakni media karburasi, suhu pemanasan, waktu penahanan dan proses pendinginan [3] [7].

Penelitian Pack Carburizing pada material ST 37 yang merupakan baja karbon rendah [5] menunjukkan bahwa terdapat peningkatan kekerasan setelah dilakukannya Pack Carburizing, dibandingkan dengan material tanpa perlakuan. Pada penelitian ini peneliti menggunakan Media karburasi arang tempurung kelapa, Suhu Pemanasan $950^{\circ} \mathrm{C}$, dan lama waktu penahanan yakni 2 jam, 4 jam, 6 jam, 8 jam, dan 10 jam. Lama waktu pemanasan menjadikan tingkat kekerasan ST 37 semakin meningkat. Dengan dilakukan analisa regresi pada waktu pemanasan, mendapatkan hasil bahwa lama pemanasan sangat berpengaruh terhadap nilai kekerasan yakni sebesar $88,99 \%$.

Penelitian terhadap Sproket motor imitasi yang merupakan baja karbon rendah [3], juga menunjukkan bahwa terdapat peningkatan kekerasan setelah dilakukannya Pack Carburizing. Dalam penelitian ini, peneliti tersebut menggunakan media $80 \%$ arang kayu gelam dan 20\% serbuk cangkang remis sebagai katalisator. Selain itu juga digunakan media pendinginan berbeda yakni air, oli bekas, udara dan silikon serta suhu pemanasan yang berbeda pula yakni $850^{\circ} \mathrm{C}$ dan $900^{\circ} \mathrm{C}$. Hasil penelitian menunjukkan bahwa kekerasan tertinggi dialami sproket dengan suhu pemanasan $900^{\circ} \mathrm{C}$ dan berpendingin air. Peningkatan kekerasan tersebut yakni sebesar 43,07 \% dari kondisi tanpa perlakuan. Dari penelitian ini juga didapatkan bahwa unsur yang mengalami kenaikan signifikan yakni karbon (C) dan silicon (Si) Sebesar 82,39\% dan 404,4\%.

Pada penelitian ini, karbon yang digunakan dapat diperoleh dari arang kayu jati[6]. Penggunaan $100 \%$ arang kayu jati disebabkan karena umumnya pada peneliti menggunakan energizer atau katalisator untuk mempercepat proses karburasinya. Padahal tanpa energizer-pun dapat terjadi proses karburasi saat pemanasan baja pada suhu tinggi hingga mencapai temperature austenite. Hal tersebut dapat terjadi, karena karbon teroksidasi oleh oksigen yang terperangkap dalam kotak menjadi $\mathrm{CO}_{2}$. Dengan temperatur yang semakin tinggi keseimbangan reaksi makin cenderung ke kanan yang mengakibatkan banyaknya CO. Pada permukaan material baja, $\mathrm{CO}$ akan terurai, dimana $\mathrm{C}$ yang terbentuk berupa atom karbon yang dapat masuk dan berdifusi pada fase austenit dari baja tersebut. Pada penelitian ini, peneliti melakukan uji coba terhadap pengaruh media arang kayu jati $100 \%$ pada proses pack carburizing. Media tersebut digunakan sebagai media karburasi, serta dilakukan pula variasi waktu penahanan saat pemanasan pada temperatur austenite. Hal ini dilakukan untuk mengetahui dampaknya terhadap komposisi kimia dan kekerasan baja karbon rendah. Tujuan penelitian ini adalah mendapatkan baja karbon rendah yang memiliki nilai kekerasan dan komposisi karbon yang lebih tinggi daripada material awal dengan menggunakan media arang kayu jati $100 \%$.

\section{METODE}

\section{A. Material Uji}

Material uji yang digunakan pada penelitian ini yakni spare parts sproket imitasi motor retro. Material uji dipersiapkan terlebih dahulu dengan cara melakukan potongan sesuai kebutuhan pengujian kekerasan[8]. Material yang telah siap kemudian dilakukan pengujian komposisi tahap awal sebelum dilakukan pck carburizing.

\section{B. Proses Pack Carburizing}

Sebelum dilakukan proses ini, maka terlebih dahulu disiapkan media carburizer-nya. Media yang digunakan yakni arang kayu jati. Tahapan Proses pack carburizing yang dilakukan yakni[9][10]:

1. Material benda uji dan serbuk arang kayu jati dimasukkan ke dalam kotak pack carburizing. Material ditempatkan di tengah antar serbuk arang kayu jati. Penempatan antar material yang satu dengan yang lain diberikan jarak sama, kemudian kotak ditutup rapat[11].

2. Kotak yang sudah siap tersebut dimasukkan ke dalam dapur pemanas.

3. Dapur pemanas dihidupkan dan dilakukan pemanasan awal (pre-heating) yakni $650^{\circ} \mathrm{C}$ dengan waktu penahanan 1 jam. Setelah mencapai waktu penahanan pada suhu tersebut, kemudian suhu dapur pemanas dinaikkan $900^{\circ} \mathrm{C}$ serta dilakukan variasi waktu penahanan sebesar 5, 6 dan 7 jam[12][13].

4. Kotak dikeluarkan kemudian material didinginkan dengan air [14].

5. Material yang sudah dikeluarkan, kemudian dibersihkan untuk dipersiapkan melakukan pengujian.

\section{Pengujian Komposisi Material}

Setelah dilakukan proses pack carburizing, kemudian dilakukan pengujian komposisi kimia. Hal ini dilakukan untuk menganlisa pengaruh penambahan unsur pada proses tersebut. Hasil dari pengujian ini kemudian dibandingkan dengan material sebelum dilakukan proses pack carburizing.

\section{Pengujian Kekerasan}

Pengujian kekerasan juga dilakukan pada material sebelum dan setelah proses pack carburizing. Hal ini dilakukan untuk menganalisa perbedaan kekerasan dan membandingkannya dengan material uji sebelum proses pack carburizing. Pengujian kekerasan dilakukan dengan metode uji kekerasan rockwell skala A. 


\section{HASIL DAN DISKUSI}

\section{A. Hasil Pengujian Komposisi Material}

Material yang diuji pada proses ini yakni material spare parts sebelum dan sesudah proses pack carburizing. Hasil dari pengujian ini dapat dilihat pada tabel 1 .

TABEL 1

TABEL KOMPOSISI MATERIAL SEBELUM DAN SESUDAH PROSES PACK CARBURIZING

\begin{tabular}{|c|c|c|c|c|}
\hline $\begin{array}{c}\text { Unsur } \\
\text { Material }\end{array}$ & $\begin{array}{c}\text { Material } \\
\text { sebelum } \\
\text { diuji } \\
\mathbf{( \% )}\end{array}$ & $\begin{array}{c}\text { Material } \\
\text { setelah } \\
\text { diuji } \\
\text { (waktu } \\
\text { penahanan } \\
\text { 5 jam) (\%) }\end{array}$ & $\begin{array}{c}\text { Material } \\
\text { setelah } \\
\text { diuji } \\
\text { (waktu } \\
\text { penahanan } \\
\text { 6 jam) (\%) }\end{array}$ & $\begin{array}{c}\text { Material } \\
\text { setelah } \\
\text { diuji } \\
\text { (waktu } \\
\text { penahanan } \\
\text { 7 jam) (\%) }\end{array}$ \\
\hline Fe & 99,1 & 98,2 & 98,2 & 97,8 \\
\hline $\mathbf{M n}$ & 0.35 & 0,31 & 0,29 & 0,25 \\
\hline $\mathbf{C}$ & 0,12 & 1,03 & 1,18 & 1,37 \\
\hline $\mathbf{S i}$ & 0,14 & 0,23 & 0,23 & 0,24 \\
\hline $\mathbf{C r}$ & 0,02 & 0,027 & 0,031 & 0,045 \\
\hline $\mathbf{M o}$ & 0,06 & 0,064 & 0,043 & 0,014 \\
\hline $\mathbf{C u}$ & 0,04 & 0,025 & 0,024 & 0,026 \\
\hline $\mathbf{N i}$ & 0,02 & 0,045 & 0,03 & 0,165 \\
\hline $\mathbf{P}$ & 0,018 & 0,005 & 0,004 & 0,006 \\
\hline $\mathbf{S}$ & 0,018 & 0,012 & 0,012 & 0,012 \\
\hline $\mathbf{T i}$ & 0,0001 & 0,050 & 0,006 & 0,10 \\
\hline $\mathbf{N}$ & 0,0005 & 0,055 & 0,082 & 0,16 \\
\hline
\end{tabular}

Berdasarkan pengujian komposisi material. Material sproket imitasi ini termasuk kategori baja karbon rendah. Hal ini disebabkan kadar karbon kurang dari $0,25 \%$ yakni sebesar $0,12 \%$. Setelah dilakukan proses pack carburizing kadar karbon pada material ini semakin meningkat. Peningkatan ini terjadi seiring dengan lamanya waktu penahanan yang dikenakan pada material. Peningkatan yang terjadi tersebut, antara $1,03 \%$ sampai $1,37 \%$. Nilai ini membuktikan bahwa proses pack carburizing dengan menggunakan 100\% arang kayu jati berhasil meningkatkan kadar karbon dalam material. Hal ini dapat terjadi dikarenakan material terdifusi saat berada di tengah karbon aktif pada suhu $900^{\circ} \mathrm{C}$ di dalam dapur pemanas. Selain carbon, unsur lain seperti Mn mengalami penurunan jumlah unsur dibandingkan sebelum perlakukan. Penurunan terbesar dialami saat waktu penahanan panas 7 jam yakni $0,25 \%$. Unsur Si mengalami kenaikan jumlah unsur dibandingkan sebelum perlakukan. Kenaikan terbesar terjadi pada waktu penahanan 7 jam yakni 0,24\%. Penurunan unsur $\mathrm{Mn}$, kenaikan unsur Si dan unsur-unsur yang lain, tidak memberikan pengaruh terhadap sifat material. Hal ini terjadi karena unsur karbon yang naik signifikan, sehingga hal tersebut menjadi dominan dalam perubahan sifat material. Kenaikan unsur karbon ini berpengaruh saat proses pendinginan cepat setelah pemanasan, proses ini sesuai dengan diagram CTT pada gambar 1 .

Dari diagram CTT pada gambar 1, dapat digambarkan bahwa baja yang telah diaustenisasi kemudian didinginkan cepat maka struktur akhir yang didapatkan yakni martensit. Struktur martensit ini yang menyebabkan material uji menjadi semakin keras. Baja karbon rendah tidak bisa mempunyai struktur akhir berupa martensit walaupun telah mengalami austenisasi dan dinginkan cepat. Oleh karena itu diperlukan penambahan karbon terlebih dahulu sehingga baja yang telah diaustenisasi dan didinginkan cepat bisa berubah strukturnya menjadi martensit.

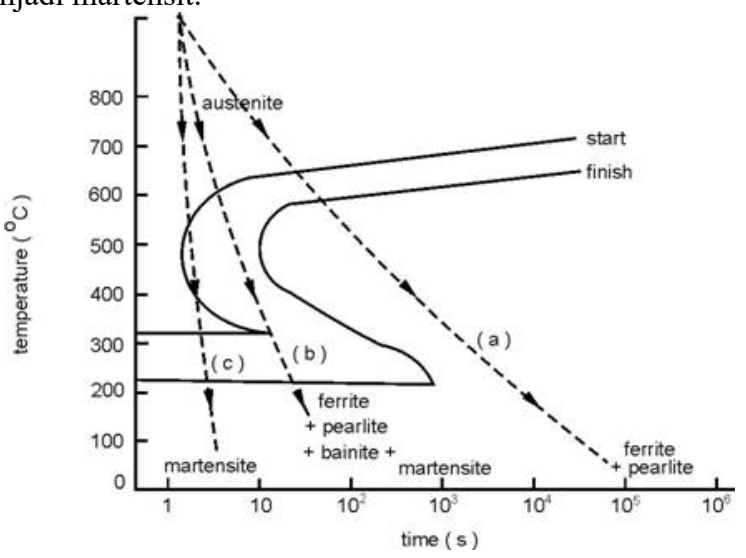

Gbr 1. Diagram CTT (Continuous Cooling Transformation)

\section{B. Hasil Uji Kekerasan}

Pengujian kekerasan yang dilakukan pada penilitian ini menggunakan metode uji kekerasan rockwell A. Material yang diuji yakni material sebelum dan sesudah dilakukan pack carburizing. Pada pengujian ini dilakukan pengambilan data pada permukaan benda uji. Pengujian dilakukan dengan identor intan kerucut dengan beban 588,04 N. Tiap material uji dilakukan pengujian sebanyak 5 titik. Pada tabel 2 dan 3 disajikan hasil pengujian kekerasan material sebelum dan setelah mengalami pack carburizing.

TABEL 2

Tabel Hasil Pengujian KeKerasan Non Perlakuan

\begin{tabular}{|c|c|c|c|}
\hline No & Jenis perlakuan & $\begin{array}{c}\text { Titik } \\
\text { Uji }\end{array}$ & $\begin{array}{c}\text { Nilai Kekerasan } \\
\text { (HRA) }\end{array}$ \\
\hline 1 & \multirow{5}{*}{ Non Perlakuan } & 1 & 46,5 \\
\hline 2 & & 2 & 46,5 \\
\hline 3 & & 3 & 46 \\
\hline 4 & & 4 & 46,5 \\
\hline 5 & & 5 & 46,5 \\
\hline \multicolumn{3}{|c|}{ Jumlah } & 232 \\
\hline \multicolumn{3}{|c|}{ Rata-Rata } & 46,4 \\
\hline
\end{tabular}


TABEL 3

Tabel Hasil Pengujian KeKerasan Setelah PROSES PACK CARBURIZING

\begin{tabular}{|c|c|c|c|c|c|}
\hline \multirow[b]{2}{*}{ No } & \multirow{2}{*}{$\begin{array}{c}\text { Jenis } \\
\text { perlakuan }\end{array}$} & \multirow{2}{*}{$\begin{array}{c}\text { No. } \\
\text { Titik } \\
\text { Uji }\end{array}$} & \multicolumn{3}{|c|}{ Nilai Kekerasan (HRA) } \\
\hline & & & $\begin{array}{c}\text { Sample } \\
1\end{array}$ & $\begin{array}{c}\text { Sample } \\
2\end{array}$ & $\begin{array}{c}\text { Sample } \\
3\end{array}$ \\
\hline 1 & \multirow{5}{*}{$\begin{array}{c}\text { Waktu } \\
\text { Penahanan } \\
5 \text { Jam }\end{array}$} & 1 & 83 & 82.2 & 81.3 \\
\hline 2 & & 2 & 85.3 & 84.5 & 85 \\
\hline 3 & & 3 & 85.5 & 83 & 84.5 \\
\hline 4 & & 4 & 85.5 & 82 & 84.5 \\
\hline 5 & & 5 & 85 & 81.3 & 82.3 \\
\hline \multicolumn{3}{|c|}{ Jumlah } & 424.3 & 413 & 417.6 \\
\hline \multicolumn{3}{|c|}{ Rata-Rata } & 84.86 & 82.60 & 83.52 \\
\hline 1 & \multirow{5}{*}{$\begin{array}{c}\text { Waktu } \\
\text { Penahanan } \\
6 \text { Jam }\end{array}$} & 1 & 85.3 & 85 & 84.5 \\
\hline 2 & & 2 & 82.5 & 84 & 84 \\
\hline 3 & & 3 & 84.5 & 84.3 & 85 \\
\hline 4 & & 4 & 85 & 86 & 85 \\
\hline 5 & & 5 & 85 & 85.3 & 85 \\
\hline \multicolumn{3}{|c|}{ Jumlah } & 422.3 & 424.6 & 423.5 \\
\hline \multicolumn{3}{|c|}{ Rata-Rata } & 84.46 & 84.92 & 84.7 \\
\hline 1 & \multirow{5}{*}{$\begin{array}{c}\text { Waktu } \\
\text { Penahanan } \\
7 \text { Jam }\end{array}$} & 1 & 85 & 84.5 & 84.5 \\
\hline 2 & & 2 & 85 & 85 & 84 \\
\hline 3 & & 3 & 85 & 85 & 85.5 \\
\hline 4 & & 4 & 85 & 84.5 & 85 \\
\hline 5 & & 5 & 84 & 85.3 & 85 \\
\hline \multicolumn{3}{|c|}{ Jumlah } & 424 & 424.3 & 424 \\
\hline \multicolumn{3}{|c|}{ Rata-Rata } & 84.8 & 84.86 & 84.8 \\
\hline
\end{tabular}

Berdasarkan tabel 2 dan 3 menunjukkan nilai yang bervariasi pada tiap titik uji. Pada material sebelum perlakukan, pengujian dilakukan di 1 sample uji, sedangkan di material uji setelah perlakukan dilakukan di 3 sample uji. Pada tiap sample uji setelah perlakuan dilakukan pengujian sebanyak 5 titik uji. Diagram perbandingan kekerasan sebelum dan sesudah proses pack carburizing dapat dilihat pada gambar 2 .

\section{Diagram Hasil Rata-Rata Uji Kekerasan}

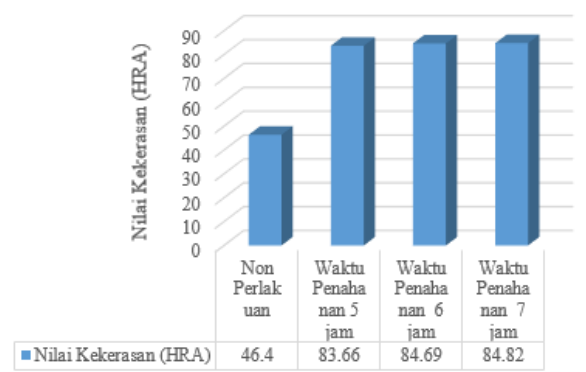

Gbr. 2 Diagram hasil rata-rata uji kekerasan
Dari diagram tersebut dapat dilihat nilai rata-rata kekerasan tertinggi pada meterial uji setelah pack carburizing terdapat pada sample uji yang mengalami waktu penahanan 7 jam yakni 84,82 HRA. Rata-rata nilai kekerasan meterial uji setelah pack carburizing terendah dialami material uji dengan waktu penahanan 5 jam yakni 83,66 HRA. Dari gambar itu juga dapat dilihat bahwa material yang mengalami pack carburizing mengalami peningkatan kekerasan dari 80, 30\% sampai $82,80 \%$ jika dibandingkan material yang belum mengalami pack carburizing.

Data hasil pengujian kekerasan setelah proses pack carburizing kemudian dilakukan uji statistik dengan menggunakan software. Pengujian yang pertama yakni uji uji homogenitas varians seperti yang ditampilkan pada Tabel 4. Dari pengujian tersebut didaptkan data bahwa $\mathrm{F}$ hitung berdasarkan median yakni 7,659 dengan sign 0,001 . Oleh karena nilai sign $>0,05$ maka dapat disimpulkan varians antar kelompok bersifat homogen.

TABEL 4

HASIL UJI HOMOGENITAS VARIANS

\begin{tabular}{ll|r|r|r|r} 
& \multicolumn{1}{c}{$\begin{array}{l}\text { Levene } \\
\text { Statistic }\end{array}$} & \multicolumn{1}{c}{ df1 } & \multicolumn{1}{c}{ df2 } & \multicolumn{1}{c}{ Sig. } \\
\hline Nilai Kekerasan & Based on Mean & 21.181 & 2 & 42 & .000 \\
\cline { 2 - 6 } & Based on Median & 7.659 & 2 & 42 & .001 \\
\cline { 2 - 6 } & $\begin{array}{l}\text { Based on Median and } \\
\text { with adjusted df }\end{array}$ & 7.659 & 2 & 26.568 & .002 \\
\cline { 2 - 6 } & Based on trimmed mean & 20.571 & 2 & 42 & .000 \\
\hline
\end{tabular}

Setelah dilakukan uji homogenitas varians kemudian dilakukan uji ANOVA yang hasilnya seperti dapat dilihat pada Tabel 5. Pada gambar tersebut ditampilkan hasil uji beda rata-rata secara keseluruhan. Pada gambar tabel tersebut dapat diketahui nilai $\mathrm{F}$ hitung sebesar 5,603 dengan sign 0,007. Dikarenakan nilai sign $<0,05$, maka Ho ditolak sehingga dapat disimpulkan terdapat perbedaan rata-rata nilai kekerasan pada waktu penahanan 5 jam, 6 jam dan 7 jam.

TABEL 5

HASIL UJI ANOVA

\begin{tabular}{|c|c|c|c|c|c|}
\hline & $\begin{array}{l}\text { Sum of } \\
\text { Squares }\end{array}$ & df & Mean Square & $\mathrm{F}$ & Sig. \\
\hline Between Groups & 12.147 & 2 & 6.074 & 5.603 & .007 \\
\hline Within Groups & 45.529 & 42 & 1.084 & & \\
\hline Total & 57.676 & 44 & & & \\
\hline
\end{tabular}

Dikarenakan nilai pengujian yang signifikan pada uji ANOVA maka peneliti melanjutkan ke uji post hoc. Hasil dari uji post hoc seperti yang ditampilkan pada Tabel 6. Uji lanjut ini digunakan untuk mengetahui perbedaan secara spesifik sekaligus untuk mengetahui nilai kekerasan tertinggi dari ke tiga waktu penahanan pada proses pack carburizing. Dari gambar tabel tersebut dapat dilihat perbedaan nilai kekerasan antara antara waktu penahanan 5 jam dan 6 jam diperoleh nilai $\operatorname{sig}=0,010$, Oleh karena nilai sig $<0,05$ dapat disimpulkan bahwa ada perbedaan nilai kekerasan antara waktu penahanan 5 jam dan 6 jam. Dalam hal ini nilai kekerasan pada waktu penahanan 5 jam lebih rendah daripada waktu penahanan 6 
jam. Hal yang sama juga terjadi pada perbedaan nilai kekerasan 5 jam dengan 7 jam. Nilai sig yang diperoleh dari perbedaan tersebut sig $=0,004$, oleh karena nilai sig $<0,05$ maka juga terdapat perbedaan nilai kekerasan antara waktu penahanan 5 jam dan 7 jam. Dalam hal ini nilai kekerasan pada waktu penahanan 5 jam lebih rendah daripada waktu penahanan 7 jam. Hal yang berbeda terjadi pada perbedaan nilai kekerasan 6 jam dengan 7 jam. Nilai sig yang diperoleh dari perbedaan sig tersebut sig $=0,741$, dikarenakan nilai sig $>0,05$ maka tidak terdapat perbedaan signifikan nilai kekerasan antara waktu penahanan 6 jam dan 7 jam.

TABEL 6

HASIL UJI POST HOC

Dependent Variable: Nilai Kekerasan

LSD

\begin{tabular}{|c|c|c|c|c|c|c|}
\hline \multirow[b]{2}{*}{ (I) Waktu } & \multirow[b]{2}{*}{ (J) Waktu } & \multirow{2}{*}{$\begin{array}{c}\text { Mean } \\
\text { Difference (I- } \\
\mathrm{J})\end{array}$} & \multirow[b]{2}{*}{ Std. Error } & \multirow[b]{2}{*}{ Sig. } & \multicolumn{2}{|c|}{$95 \%$ Confidence Interval } \\
\hline & & & & & Lower Bound & Upper Bound \\
\hline \multirow[t]{2}{*}{5 jam } & $6 \mathrm{jam}$ & $-1.03333^{\star}$ & .38018 & .010 & -1.8006 & -.2661 \\
\hline & $7 \mathrm{jam}$ & $-1.16000^{*}$ & .38018 & .004 & -1.9272 & -.3928 \\
\hline \multirow[t]{2}{*}{$6 \mathrm{jam}$} & $5 \mathrm{jam}$ & $1.03333^{\star}$ & .38018 & .010 & .2661 & 1.8006 \\
\hline & $7 \mathrm{jam}$ & -.12667 & .38018 & .741 & -.8939 & .6406 \\
\hline \multirow[t]{2}{*}{$7 \mathrm{jam}$} & $5 \mathrm{jam}$ & $1.16000^{\circ}$ & .38018 & .004 & .3928 & 1.9272 \\
\hline & $6 \mathrm{jam}$ & .12667 & .38018 & .741 & -.6406 & .8939 \\
\hline
\end{tabular}

Pada data tersebut dapat disimpulkan bahwa kekerasan pada permukaan material uji tidak merata. Hal ini disebabkan karena kekerasan baja tergantung dari besarnya struktur martensit yang terjadi serta ukuran butirnya. Dimana semakin kecil ukuran butir tersebut maka semakin tinggi nilai kekerasannya begitupun sebaliknya. Besar kecil ukuran butir tersebut bergantung pada laju pendinginan yang dialami spesimen tersebut. Pada penelitian ini, hal tersebut terjadi karena beda laju pendinginan antar permukaan yang berbeda saat proses pencelupan quenching dengan air. Pada material uji yang mengalami proses pack carburizing, terdapat kenaikan nilai kekerasan pada waktu penahanan yang semakin lama. Akan tetapi waktu penahanan hingga 7 jam tidak disarankan untuk dilakukan pada proses pack carburizing dengan media arang kayu jati 100\%. Hal ini dikarenakan kenaikan nilai kekerasan yang terjadi tidak signifikan. Kenaikan kekerasan antara sebelum dan sesudah proses ini dapat terjadi karena unsur karbon terdifusi seiring bertambahnya waktu penahanan kedalam material. Proses ini juga berhubungan dengan semakin bertambahnya jumlah prosentase karbon pada material di tiap kenaikan waktu penahanan serta penahanan ukuran butir pada waktu pendinginan. Penambahan jumlah Karbon ini dapat menyebabkan perubahan struktur martensit. Perubahan tersebut terjadi saat material diaustenisasi agar karbon terdifusi kedalam material, kemudian didinginkan cepat dengan media air untuk didapatkan struktur martensit dan mempertahankan ukuran butir, seperti yang digambarkan pada gambar 1. Hasil proses ini menyebabkan kekerasan material uji menjadi meningkat.

\section{KESIMPULAN}

Hasil dari penelitian dan pembahasan tentang proses pack carburizing dengan media arang kayu jati pada baja karbon rendah, maka dapat disimpulkan sebagai berikut:

1. Terdapat peningkatan jumlah karbon pada material baja karbon rendah yang mengalami pack carburizing dengan media arang kayu jati $100 \%$. Nilai karbon sebelum perlakuan yakni $0,12 \%$ meningkat saat dilakukan pemanasan pada suhu $900{ }^{\circ} \mathrm{C}$ menjadi $1,03 \%$ pada waktu penahanan 5 jam, 1,18\% pada waktu penahanan 6 jam dan $1,37 \%$ pada waktu penahanan 7 jam. Semakin lama waktu penahanan saat proses perlakuan, maka jumlah karbon yang terdifusi juga semakin meningkat. Hal ini yang menyebabkan terjadinya peningkatan jumlah unsur karbon seiring dengan bertambahnya waktu penahanan pemanasan.

2. Terdapat peningkatan nilai kekerasan pada material baja karbon rendah yang mengalami pack carburizing dengan media arang kayu jati $100 \%$. Nilai kekerasan rata-rata pada mulanya sebelum perlakuan yakni 46,4 HRA ratarata meningkat menjadi yakni 83,66 HRA, 84,69 HRA dan 84, 82 HRA pada penahanan 5 jam. 6 jam dan 7 jam. Namun saat dilakukan uji statistik, tidak disarankan untuk dilakukan penahanan waktu pemanasan hingga 7 jam jika menggunakan media ini. Hal ini disebabkan hasil perbandingan perubahan kekerasan antara waktu penahanan 6 jam dengan 7 jam tidak terdapat kenaikan kekerasan yang cukup signifikan.

\section{REFERENSI}

[1] R. G. Budynas and J. K. Nisbett, Machine design, X., no. I. New York: McGraw-Hill Education, 2015.

[2] S. Tata, Sudira, Saito, Pengetahuan Bahan Teknik, 4th Editio. Jakarta: PT. Pradnya Paramita, 1985.

[3] E. Sundari, R. Fahlevi, and B. Besar, "Analisa Pengaruh Pack Carburizing Terhadap Sifat Mekanis Sprocket Imitasi Sepeda Motor Menggunakan Arang Kayu Gelam Dan Serbuk Cangkang Remis Sebagai Katalisator," J. Austenit, vol. X, no. 2, pp. 72-78, 2018.

[4] H. Anrinal, Metalurgi Fisik, First. Yogyakarta: Penerbit Andi, 2013.

[5] Apriatun, Taufikurahman, and E. Sundari, "Analisa Pengaruh Variasi Waktu Penahanan Pada Proses Pack Carburizing Terhadap Kekerasan Baja Karbon Rendah ST 37," Mach. J. Teknol. Terap., vol. II, no. 1, pp. 23-27, 2021.

[6] O. Kurniawan and N. S. Drastiawati, "Pengaruh Variasi Media Arang Tempurung Kelapa, Tongkol Jagung, Dan Kayu Jati Pada Metode Pack Carburizing Terhadap Kekerasan Dan Struktur Mikro Baja SS400," J. Tek. Mesin, vol. VII, no. 02, pp. 55-62, 2019.

[7] K. Suarsana, C. I. Putri K, and I. M. Astika, "Pengaruh Perlakuan Temperatur dan Waktu Penahanan Pack Carburizing Terhadap Umur Lelah Baja St 42," J. Energi Dan Manufaktur, vol. XI, no. 1, pp. 21-24, 2018.

[8] Bahtiar, M. Iqbal, and D. Arisandi, "Analisis Kekerasan Dan Struktur Mikro Pada Baja Komersial Yang Mendapatkan Proses Pack Carburazing Dengan Arang 
Kelapa Sawit,” J. Mek., vol. 8, no. 1, pp. 686-696, 2017.

[9] Karmin, S. Effendi, Firdaus, and Romli, "Analisa Perubahan Sifat Mekanik Dan Struktur Mikro Multi Quenching Terhadap Hasil Pack Carburizing Baja Karbon Rendah," $J$. Austenit, vol. 10, no. April, pp. 34-42, 2018.

[10] Supriyanto and Ismanto, "Analisa Pengaruh Holding Time pada Proses Karburasi dalam Media Arang Kayu Jati terhadap Kekerasan Baja ST-37," J. Mesin Nusant., vol. 3, no. 1, pp. 29-36, 2020.

[11] D. N. K. P. Negara, "EfektifitasCarburizer dari Sumber Karbon Berbeda Pada Proses Pack Carburizing," $J$. METTEK, vol. 2, no. 1, pp. 5-10, 2016.

[12] N. Nurlina, R. M. Bisono, and D. Irawan, "Pengaruh Variasi Temperature Dan Holding Time Pack Carburizing Menggunakan Media Arang Serbuk Gergaji Kayu Untuk Material Pisau," J. Technopreneur, vol. 8, no. 2, pp. 129$134,2020$.

[13] O. D. Rerung and D. N. Ully, "Perancangan pack carburizing dengan metoda eksperimen sungguhan menggunakan arang lamtoro lokal pulau timor," $J$. SIMETRIS, vol. 10, no. 2, pp. 553-564, 2019.

[14] D. Satria et al., "Pengaruh Waktu Tahan Proses Pack Carburizing Baja AISI 3115 dengan Menggunakan Calcium Carbonat dan Batubara Sub Bituminous dan Mendapatkan Perlakuan Panas Quenching Media Pendingin Air," Rotasi, vol. 21, no. 2, pp. 88-95, 2019.

[15] I. P. A. A. Payadnya and I. G. A. N. T. Jayantika, Panduan Penelitian Eksperimen Beserta Analisis Statistik dengan SPSS, 1st Editio. Sleman: CV Budi Utama, 2018. 